\title{
Proof of Discriminatory Intent under Title VII: United States Postal Service Board of Governors v. Aikens
}

\section{Citation}

Elizabeth Bartholet, Proof of Discriminatory Intent under Title VII: United States Postal Service Board of Governors v. Aikens, 70 Calif. L. Rev. 1201 (1982).

\section{Published Version}

http://scholarship.law.berkeley.edu/californialawreview/vol70/iss5/2/

\section{Permanent link}

http://nrs.harvard.edu/urn-3:HUL.InstRepos:13031850

\section{Terms of Use}

This article was downloaded from Harvard University's DASH repository, and is made available under the terms and conditions applicable to Other Posted Material, as set forth at http:// nrs.harvard.edu/urn-3:HUL.InstRepos:dash.current.terms-of-use\#LAA

\section{Share Your Story}

The Harvard community has made this article openly available.

Please share how this access benefits you. Submit a story.

Accessibility 


\section{California Law Review}

Volume 70 | Issue 5

Article 2

September 1982

\section{Proof of Discriminatory Intent under Title VII: United States Postal Service Board of Governors v. Aikens}

Elizabeth Bartholet

Follow this and additional works at: http://scholarship.law.berkeley.edu/californialawreview

\section{Recommended Citation}

Elizabeth Bartholet, Proof of Discriminatory Intent under Title VII: United States Postal Service Board of Governors v. Aikens, 70 CAL. L. Rev. 1201 (1982).

Available at: http://scholarship.law.berkeley.edu/californialawreview/vol70/iss5/2

This Article is brought to you for free and open access by the California Law Review at Berkeley Law Scholarship Repository. It has been accepted for inclusion in California Law Review by an authorized administrator of Berkeley Law Scholarship Repository. For more information, please contact jcera@law.berkeley.edu. 


\title{
Proof of Discriminatory Intent Under Title VII: United States Postal Service Board of Governors v. Aikens
}

\author{
Elizabeth Bartholet $\uparrow$
}

\section{INTRODUCTION}

The Supreme Court will hear a case this Term involving the question of how intentional discrimination in employinent can be proven. The case-United States Postal Service Board of Governors v. Aikens 1 involves a claim brought under title VII of the Civil Rights Act of 1964. ${ }^{2}$ Aikens charged the Postal Service with racial discrimination in denying him promotion to various managerial-level jobs. The D.C. Circuit ruled that he could make out a prima facie case of discrimination by showing that he possessed all known qualifications for the promotions, and had been passed over in favor of white candidates. ${ }^{3}$ The United States Departınent of Justice, representing the Postal Service, has asked the Court to rule that plaintiff's prima facie proof must demonstrate a "probability" of discrimination. ${ }^{4}$ In this case, where the plaintiff relied on coinparative qualifications to show intent, the Government says that to make out this probability, plaintiff would have to provide evidence that he is more qualified than the candidates chosen, in terms of whatever tangible and intangible factors may be taken into

$\dagger$ Assistant Professor of Law, Harvard University. B.A. 1962, Radcliffe College; LL.B. 1965, Harvard Law School.

The author served from 1968 to 1972 as a staff attorney for the NAACP Legal Defense and Educational Fund, Inc., which is co-counsel for respondent Aikens in the case discussed herein. She has since that time continued to consult with the Legal Defense Fund on various of its cases.

1. 102 S. Ct. 1707 (1982) (No. 81-1044), granting cert. to Aikens v. United States Postal Serv. Bd. of Governors, 665 F.2d 1057 (D.C. Cir. 1981).

2. Pub. L. No. 88-352, $\$ \S 701-716,78$ Stat. $241,253-66$ (1964) (codified as amended at 42 U.S.C. $\$ \$ 2000 \mathrm{e}$ to $2000 \mathrm{e}-17$ (1976 \& Supp. IV 1980)). Title VII was made apphicable to the federal government in 1972. Equal Employinent Opportunity Act of 1972, § 11, Pub. L. No. 92261, 86 Stat. 103, 111 (codified as amended at 42 U.S.C. $§ 2000 \mathrm{e}-16$ (1976 \& Supp. IV 1980)).

3. Aikens v. United States Postal Serv. Bd. of Governors, 665 F.2d 1057 (D.C. Cir. 1981), cert. granted, 102 S. Ct. 1707 (1982). An earlier decision by the D.C. Circuit in this case, 642 F.2d 514 (D.C. Cir. 1980), was vacated and remanded by the Supreine Court, 453 U.S. 902 (1981), for reconsideration in light of Texas Dep't of Community Affairs v. Burdine, 450 U.S. 248 (1981).

4. Brief for Petitioner at 10, 19 n.14, Aikens. 
account in the Postal Service's promotional decisionmaking system. ${ }^{5}$

The definition of the requirements of plaintiffs' prima facie case is of tremendous practical significance in a title VII case. If plaintiffs fail to make out a prima facie case, judgment must be entered against them upon defendant's motion for judgment at the close of plaintiff's case. (Since most title VII cases are tried without a jury, ${ }^{6}$ the court would ordinarily dismiss the case, on the inerits, pursuant to rule $41(\mathrm{~b})$ of the Federal Rules of Civil Procedure.) However, if plaintiffs succeed in making out a prima facie case, judgment must be entered for them, unless the defendant produces satisfactory rebuttal evidence. Thus in an intentional discrimination case, plaintiff's' prima facie proof is said to create a "legally mandatory, rebuttable presuinption" of discrimimation. $^{7}$ This has the effect of forcing the defendant einployer to produce evidence to rebut the presumption of discrimination at the risk of losing the case.

The key issue posed by Aikens relates to the point at which this burden of production should be placed on the employer. The D.C. Circuit held, in effect, that plaintiff inust show in his mitial case only what he could, with reasonable effort, be expected to learn prior to trialnamely, that he possessed all known qualifications. This showing would place the burden of production on the einployer to provide evidence as to wliy it selected whites over an apparently qualified black candidate-evidence that would presumably include information as to how the employer's discretionary proinotional system measured qualifications. The Government argues that since in an intentional discrimination case plaintiff has the ultimate burden of persuasion on the issue of illicit intent, plaintiff must deinonstrate a probability of illicit imtent in his imitial proof. No burden of production should be placed on the defendant until such a probability is made out.

The maimer in which this issue is resolved will significantly affect the substantive meaning of the ban on intentional discrimination contained in title VII and other job discrimination legislation. This is because of the nature of intentional discrimination in today's world. Overt and blatant discrimination is a relatively rare plenomenon. The very existence of title VII, witl its ban on discrimination, and its provi-

5. Id. at $10,23,24 \mathrm{n} .18$. The Government says that a probability of discrimmation can also be proved by a showing that the employer's decision was economically irrational, or by statistical evidence that an employer has consistently hired a disproportionately small number of mimorities, or by anecdotal evidence of racial prejudice. Id. at 11.

6. Title VII has been interpreted not to provide a right to jury trial even when back pay claims are mvolved. See, e.g., Slack v. Havens, 522 F.2d 1091, 1094 \& n.4 (9th Cir. 1975) (restitution for back pay is an equitable and not a legal remedy); EEOC v. Detroit Edison Co., 515 F.2d 301, 308 (6th Cir. 1975), vacated on other grounds and remanded, 431 U.S. 951 (1977).

7. Texas Dep't of Community Affairs v. Burdine, 450 U.S. 248, 254 n.7 (1981). 
sions guaranteemg victims the right to damages, injunctive relief, and attorneys' fees, has meant the elimination of most sucl discrimination by most employers. It is intentional discrimination in its covert, hidden form that now poses the real problem. Evidence of illicit intent may be extremely difficult to obtain, whether the responsible individuals are conscious of their bias, and therefore likely to try to hide it, or whether they are expressing unconscious bias through some discretionary decisionmaking process. Plaintiffs' chances of proving illicit intent will, therefore, turn to a great degree on judicial rulings as to what kind of evidence of such intent plaintiffs are required to produce at various stages of the trial process, and with what kind of assistance from the employer.

The position that the Government is taking in the Aikens case would, if accepted by the Supreme Court, shape the "disparate treatment" doctrime, which defines the standards by which intentional discrimination is proven under title VII, in a way that would make it extremely difficult for plaintiffs to uncover evidence of illicit intent in most cases. And in cases where the challenged decisionmaking system includes elements of subjectivity and discretion, the Government's proposed standard may make it nearly impossible to prove such imtent. ${ }^{8}$

The disparate treatment doctrime is, of course, only one of the two main doctrines that have been developed to interpret and enforce title VII. The other is the "disparate impact" doctrine, whicl governs unintentional discrimination, and holds that certain employer practices having an adverse impact on minorities are unlawful unless the employer can prove that they are "job-related." The impact doctrine has been an enormously powerful weapon for plaintiffs, because it removes any necessity to prove illicit motive on the employer's part, and because the burden of proof placed on the employer to sliow job-relatedness has turned out to be very difficult to satisfy. ${ }^{10}$

However, the disparate treatment doctrine remains of great importance. Courts generally apply disparate treatment analysis to cases of individual, rather than class-directed, discrimination. And they generally apply disparate treatment analysis to employment decisionmaking systems that rely on discretion and subjective judgment; the courts are thus far divided on the issue of whether the impact doctrine should be

8. The Government's standard would thus further the dichotomy between judicial treatment of "upper level" as compared with "lower level" jobs-a dichotomy that is discussed and criticized in Bartholet, Title VII's Application to Jobs in High Places, 95 HARv. L. Rev. 945 (1982) (courts have effectively immunized society's more desirable jobs from the doctrines that have been routimely apphed to blue collar jobs in the last fifteen years).

9. The leading Supreme Court case adopting this doctrine is Griggs v. Duke Power Co., 401 U.S. 424 (1971).

10. See Bartholet, supra note 8, at 950-55. 
applied to require einployers to provide convincing proof of job-relatedness with respect to sucl systems. ${ }^{11}$ Moreover, the impact doctrine's future is somewhat uncertain. Prominent officials in the Reagan Administration have made clear their concern about the use of the impact doctrine. ${ }^{12}$ And the Supreme Court has slown itself reluctant to expand the impact doctrine's applicability. ${ }^{13}$ In the future, therefore, disparate treatment analysis may be all that is available to plaintiffs charging job discrimination in a wide variety of contexts.

Moreover, the principle that the Government is proposing in Aikens would, if accepted by the Court, significantly undermine the disparate impact doctrine as well as the disparate treatment doctrine. This principle is that plaintiffs must provide, as part of their prima facie case, evidence demonstrating probability as to the ultimate fact at issue. In an impact case, the ultimate fact at issue is the existence of unjustified adverse impact on minorities. The Government's principle would seem logically to lead to a requirenent that plaintiffs produce evidence in their prima facie case that challenged systems are not job-related. ${ }^{14}$ The radical changes that have been wrought by the disparate iinpact doctrine are largely attributable to the fact that it has placed on defendants the burden of production and persuasion on the job-relatedness issue. It has generally been assumed that if plaintiffs had to prove the absence of job-relatedness in order to prevail, they would almost never be able to do so. The Government's principle would, therefore, if carried to its logical extreme, mean the effective death of the impact doctrine.

The issue presented by the Government's position in Aikens will not necessarily be resolved in this case. Aikens' attorneys have filed a brief arguing that plaintiff introduced extensive evidence that he was, in fact, at least as qualified as the whites chosen, together with other

11. Id. at $973-78,987$.

12. See N.Y. Times, Dec. 14, 1981, at 21, col. I (Attorney General William French Smith); id., Nov. 18, 1981, at 21, col. 3 (Clarence Pendleton, Chairman, United States Civil Rights Comm'n); id., Nov. 16, 1981, at 1, col. 3 (Assistant Attorney General for Civil Rights Wilkam Bradford Reynolds).

13. See, e.g., General Bldg. Contractors Ass'n v. Pennsylvania, 102 S. Ct. $3141,3146-50$ (1982) (42 U.S.C. \& 1981 requires proof of mtent); American Tobacco Co. v. Patterson, 102 S. Ct. 1534 (1982) (seniority plans adopted after title VII became effective are not subject to challenge under disparate impact standard).

14. Distinctions could, of course, be drawn. The defendant has the burden of persuasion, as well as production, on the job-relatedness issue under the Griggs decision. In an intent case, the plaintiff has the ultimate burden of persuasion on the issue of intent. So long as Griggs is considered to be good law on the burden of persuasion issue, there are strong arguments for leaving the burden of production on that issue on defendant also. But acceptance of the Government's principle that it is wrong to shift the burden of production in a disparate treatment case might raise questions as to the propriety of shifting the burden of persuasion in an impact case. 
evidence indicating intentional discrimination. ${ }^{15}$ The Court could well decide that the Government's proposed standard was in fact met, or it could dispose of the case in soine other way. ${ }^{16}$ But the issue presented is one that will recur, as cases involving middle and upper level job advancement are brought to court in increasing numbers. ${ }^{17}$

The purpose of this Article is to discuss some of the considerations that should be weighed in resolving this issue, as well as to point out what is at stake in terms of the substantive norms of title VII.

I

\section{Burdens of Production and Persuasion Under the Disparate TREATMENT Doctrine}

The disparate treatinent doctrime was recently clarified and refined by a unanimous Supreme Court in Texas Department of Community Affairs v. Burdine. ${ }^{18}$ Burdine, like previous disparate treatment cases, envisions three stages of proof. At the first stage plaintiffs inust present a prima facie case of discrimination. In soine cases plaintiffs inay rely in whole or in part on evidence of blatant acts of discrimination to show the employer's bad faith. Usually, however, they will rely in whole or in part on circumstantial evidence, which may simply consist of a showing that the employer has preferred whites over blacks with comparable objective qualifications. ${ }^{19}$ What kind of evidence is required will depend on the circumstances, but the evidence must at least eliminate "the most common non-discriminatory reasons" for the employer's action. ${ }^{20}$ Burdine notes that "an appropriate model" 21 is the

15. See Brief for the Respondent at 20-31, Aikens.

16. See infra note 33 .

17. Thus versions of the Aikens issue may have been presented in Powell v. Syracuse Univ., 580 F.2d 1150, 1155 (2d Cir. 1978), and in Davis v. Weidner, 596 F.2d 726, 730 (7th Cir. 1979). Both held that candidates for university level faculty positions need ouly show, to inake out a prima facie case, that they meet the basic qualifications for the positions. It is for defendant to make the initial showing of comparative qualifications in rebuttal. But see Agarwal v. Arthur G. McKee \& Co., 16 Empl. Prac. Dec. (CCH) If 8301, at 5574 (N.D. Cal. 1977), affd, 644 F.2d 803 (9th Cir. 1981); Presseisen v. Swarthmore College, 442 F. Supp. 593, 616 (E.D. Pa. 1977), affd mem, 582 F.2d 1275 (3d Cir. 1978).

18. 450 U.S. 248 (1981).

19. See generally B. Schlei \& P. Grossman, Employment Discrimination LaW 16, 115358 (1976).

20. Burdine, 450 U.S. at 254; see also International Bhd. of Teamsters v. United States, 431 U.S. 324, 358 \& n.44 (1977) ("Although the McDonnell Douglas formula does not require direct proof of discrimination, it does demand that the alleged discriminatee demonstrate at least that his rejection did not result from the two most common legitimate reasons on which an einployer might rely to reject a job applicant: an absolute or relative lack of qualifications or the absence of a vacancy in the job sought. Elimination of these reasons for the refusal to hire is sufficient, absent other explanations, to create an inference that the decision was a discriminatory one.").

21. 450 U.S. at 253 n.6. 
now-classic formula described in McDonnell Douglas Corp. v. Green.$^{22}$ There the Court held that plaintiff had made out a prima facie case of intentional discrimination by showing:

(i) that he belongs to a racial minority; (ii) that he applied and was qualified for a job for which the employer was seeking applicants; (iii) that, despite his qualifications, he was rejectcd; (iv) and that after his rejection, the position remamed open and the employer contimued to seek applieants from persons of complaimant's qualifications. ${ }^{23}$

According to Burdine, plaintiffs" prima facie case establislies a "legally mandatory, rebuttable presumption" of discrimination. ${ }^{24}$ Defendant must now produce evidence or suffer an adverse judgment. ${ }^{25}$

The Court's description of the amount of evidence tle defendant is required to produce at the second stage of proof indicates that one of the goals of the Burdine standard is to provide plamtiffs witl the kind of detailed discovery that would make it possible for them to prove illicit intent. Thus, admissible evidence articulating witl some specificity the reasons for the employment decision must be produced. ${ }^{26}$ The defendant cannot simply rest on conclusory allegations in the pleadings. ${ }^{27}$ Stage two is designed "to frame the factual issue with sufficient clarity so that the plaintiff will have a full and fair opportunity to demonstrate pretext."28 However, defendant has no burden of persuasion. He need only satisfy a burden of production by providing evidence explaining the reasons for his actions. He need not persuade the fact-finder that the reasons are sensible or job-related, or even that they are the real reasons for his action. ${ }^{29}$ The burden of persuasion on the issue of illicit intent is on plaintiff. ${ }^{30}$

At the third stage, plaintiff inust provide persuasive proof of illicit intent in order to prevail. Such proof may consist simply of evidence that the reasons proffered by defendant are not credible. ${ }^{31}$ Indeed there may be no additional presentation of evidence by plaintiff at all. Plaintiff can simply rely on his prima facie case and on cross-exannination of defendant's rebuttal witnesses. ${ }^{32}$

22. 411 U.S. 792 (1973).

23. Id. at 802 .

24. Burdine, 450 U.S. at 254 n.7.

25. See F. James \& G. Hazard, Civil Procedure $\$ \$ 7.7, .9$ (1977).

26. Burdine, 450 U.S. at 255.

27. Id. at 255 n.9.

28. Id. at $255-56$.

29. Id. at 254 .

30. Id.

31. Id. at 254-55.

32. Id. at 255 n. 10 . 
II

\section{The Issue Presented by AIKENS}

In Aikens plaintiff challenged decisions denying him proinotion to four higher level Postal Service jobs-jobs such as "Mail Processing Officer," and "Director of the Operations Division." Aikens presented evidence to the court of his objective qualifications for the jobs, showing that he satisfied all requirements, and that he coinpared favorably with the candidates selected, all of whoin were white. The pronotional decisions at issue were inade by two white supervisors, apparently on the basis of their subjective judginent of various candidates' relative qualifications.

The district court held that Aikens failed to make out a prima facie case because he had not proven that he was as or more qualified than the candidates chosen. ${ }^{33}$ The D.C. Circuit reversed, liolding that in order to make out a prima facie case, plaintiff need show no more than that he possesses the minimum objective qualifications for the job, together with any other qualifications that the defendant reveals. ${ }^{34}$ The court recognized that professional and inanagerial positions raise particularly difficult issues:

Most abilities of a successful manager-especially the ability to assume responsibility for motivating and directing other employees-are intangible, and eacli applicant could bring to the position an enormous variety of life experiences that are relevant. ${ }^{35}$

It held that proof sliould be made as follows:

At the prima facie stage, . . . the plaintiff may be required to go beyond a showing of minimum qualifications to deinonstrate that he possesses whatever qualifications or background experiences the employer has indicated are important. At the second stage, the employer must indicate which qualifications or background experiences formed the basis of his hiring or promotion decision; then, at the final stage, the

33. Aikens v. Bolger, 23 Fair Empl. Prac. Cas. (BNA) 1138 (Feb. 26, 1979) (Conclusion of Law \#8). The district court's holding is ambiguous since this finding was made at the close of a full trial, not at the end of plaintiff's prima facie case. Therefore the court's conclusion \#8 may be mtended as a holding that once defendant mtroduces rebuttal evidence, plaintiff must provide evidence that he is as or more qualified in order to satisfy his burden of persuasion on the ultimate issue of illicit imtent. The D.C. Circuit interpreted the decision below as warranting judgunent for the defendant on a motion for judginent after plaintiff's initial presentation of his case. However, the Supreine Court could reverse and remand for further consideration on the ground that the issue as to what constitutes an adequate prima facie case is not presented by the record in this case.

34. 665 F.2d 1057, 1059 (D.C. Cir. 1981), cert. granted, 102 S. Ct. 1707 (1982) (No. 81-1044).

A plaintiff who deinonstrates that he possesses the absolute minimum qualifications for a job, therefore, does not necessarily make out a prima facie case; if the employer has indicated that certain additional qualifications are necessary or preferred, the plaintiff must demonstrate that he has those qualifications as well.

35. Id. at 1060 . 
plaintiff would have to show his superiority in those areas in order to prove discrimination. ${ }^{36}$

Thus under the D.C. Circuit's standard in Aikens, plaintiffs must provide in their initial case all evidence that they can acquire with reasonable effort related to qualifications, but need not make the comparative showing of qualifications which could provide a basis for finding illicit intent until the final stage of proof, after the employer's rebuttal. The burden of production is shifted at the second stage to the employer to show how it actually evaluated qualifications.

It is worth emphasizing the difficulty of plaintiffs' ultimate task of proving illicit intent on the basis of comparative qualifications, even under the D.C. Circuit's standard. Where the promotional process includes elements of subjectivity and discretion, plaintiff cannot at the final stage of proof rely solely on comparative evidence of objective qualifications. He must imstead show, im effect, that but for racial bias he would have been found the most quahified candidate in terms of all the objective and subjective factors that the employer might have considered.

The Government argues that plaintiff must make the comparative showing of qualifications demonstrating that he is more qualified than the white candidates chosen, ${ }^{37} \mathrm{~m}$ his initial proof. Such a showing is said to be necessary to demonstrate a probability of intentional discrimination. ${ }^{38}$

The question posed by Aikens as to the standard by which the adequacy of plaintiffs' prima facie case should be evaluated has not been resolved either by Burdine or by any previous Supreine Court case. Burdine focused on the second stage of proof, simce the issue presented in that case was whether, once a prima facie case was made out, defendants had the burden of persuasion or siniply the burden of production. There is language in Burdine and other of the Supreme Court's disparate treatment cases indicating that plaimtiffs' prima facie proof should provide the basis for an "inference of discrimination," but the cases do not make clear exactly what is meant by inference of discrimination. ${ }^{39}$ The factual records im Burdine and the Court's earlier disparate treatment cases indicate that the Court has found a prima facie

36. Id.

37. See supra note 5 .

38. See supra note 4.

39. Burdine states that the prima facie case must provide evidence of circumstances which "give rise to an inference of unlawful discrimination," 450 U.S. at 253 , but does not say such evidence must show a probability of discrimination. It uses the language of probability only in quoting from an earlier decision assessing the relevance of sucli evidence "if otherwise unexplained." Id. at 254 (quoting Furnco Constr. Corp. v. Waters, 438 U.S. 567, 577 (1978)) (emphasis added). 
case made out on the basis of evidence short of what would seem required to show a probability of illicit intent. ${ }^{40}$

What does seem clear from Burdine is that it envisions a scheme of proof that would enable plaintiffs to obtam at stage two of the trial important information related to their ability to prove illicit intent. The Government's standard would radically change this scheme, and its brief indicates that this is exactly what is intended. Thus under the Government's proposed standard plaintiffs must learn everything possible that is relevant to proof of intent during discovery or other pretrial investigation. They cannot rely on the trial process to force defendants to coine forward with essential information. The Government argues that plaintiffs can obtam all information needed to prove illicit intent prior to trial. It claims that discovery can be inade effective by imposing sanctions at trial on recalcitrant defendants:

Moreover, while the question is not presented here, we suggest that, at least in some circumstances an employer's unjustified failure to provide a reason for his action, when asked to do so during discovery or an administrative investigation, may itself coinplete the prima facie case of a qualified minority applicant. ${ }^{41}$

The question of whether the Government's proposal is practicable or otherwise appropriate is discussed in the next Part.

40. Thus in McDonnell Douglas v. Green, 411 U.S. 792 (1973), the Supreme Court found that plaintiff inade out a prima facie case by showing that he satisfied the objective qualifications for the positiou. The obvious non-discriminatory reason for defendant's refusal to hire in that case was plaintiffs prior illegal conduct, directed against that very einployer, for which plaintiff had previously beeu discharged. Nonetheless the Court held that evidence relating to that reason was to be introduced in the first instance by the defendant. Id at 802-04. In Burdine the Court held that the plaintiff made out a prima facie case in a situation not very different from that presented in Aikens. Plaintiff was applying for a "project director" positiou for a division that was in trouble and threatened with termination. The einployer failed to select her and, six months later, selected another candidate, relying on an "evaluation of the relative quahifications" of the candidates. The Court found that plaintiff had satisfied her initial burden by showing that she was "qualified," leaving it to the employer to provide evidence as to the comparative qualifications. 450 U.S. at 254 n.6. In Furnco Constr. Corp. v. Waters, 438 U.S. 567 (1978), the Court held that plaintiffs made out a prima facie case based on a showing of objective qualifications, even though the most obvious reason for their not being hired was that they had applied at the gate, and the employer's selection system did not allow for consideration of at-the-gate applicants, whether white or black. The Court placed the burden on the employer to introduce evidence related to the way in which its selection systein operated, and the reasons for using that system.

Indeed, it would be a rare case in which a prima facie case that satisfied the classic $M c$ Donnell Douglas formula would provide sufficient basis to persuade a factfinder of intentional discrimination. Tliat formula requires plaintiff to show sinply that he satisfies objective job requirements, and was rejected for a job the employer was seeking to fill. As the amicus brief filed by the AFLCIO in support of the Government's position in Aikens points out, such evidence would lead to an inference of inteutional discrimination only if the selection criteria were rigid and inechanically applied, with selection autonatic once the criteria were met. As the brief notes, "that type of selection process is rare in our economy." Brief for Petitioner by AFL-CIO as Amicus Curiae at 13, Aikens.

41. Brief for Petitioner at 29, Aikens. 
The Government's argument rests on matters related to principle and policy. As a inatter of principle allegedly rooted in precedent, the argument is that the prima facie case should consist of evidence warrantimg a finding of intentional discrimination, because that is the ultimate issue in the case. As a natter of policy, employers should be protected from the burden of having to produce evidence in court in cases in which plaintiffs show no more than that they are among what may be a large group of candidates, all of whom are qualified for a given job.

\section{A. Principle and Precedent}

There is im fact nothing strange or anomalous about allowing plaintiffs to make out a prima facie case on the basis of evidence that stops short of demonstrating a probability of the ultimate fact at issue. Courts have regularly created presumptions where they seemed appropriate in order to further the goals of the substantive legal norm at issue. A presumption, by definition, requires that certain facts be presumed to be true, regardless of whether a factfinder would likely or could properly find them to be true on the basis of the evidence presented. Tlius presumptions are said to have been created in essentially two situations: (I) where B (the fact to be presumed) would be a permissible inference from $A$ (the evidence triggering the presumption), but not the only one; and (2) where B would not even be a permissible inference from $\mathrm{A} .{ }^{42}$ Presumptions are often created in part in order to shift the burden of production to the party that has the rele-

42. F. JAMES \& G. HAZARD, supra note 25 , § 7.9, at 255. See also id. \$ 7.9, at 260 ("the fact(s), A, which give rise to a presumption of $B$ in many instances are not sufficient to warrant an inference of B.").

Any previous doubt as to the constitutionahty of presumptions in the civil context seems to have been resolved, regardless of the strength of the relationship between the evidence triggering the presumption and the fact to be presumed. Thus legislative history of rule 301 of the Federal Rules of Evidence, which governs presumptions in civil cases, makes clear that the rule is based on the premise that such presumptious pose no constitutional problems, even if the basic fact has no probative value as evidence of the presumed fact. See 1 J. WeInSTEIN \& M. Berger, WeinSTEIN's EVIDENCE I 301[01], at 301-24 (1982). The relevant constitutional question is simply whether the presumption serves a rational purpose. See generally Note, Constitutionality of Rebuttable Statutory Presumptions, 55 CoLUM. L. REv. 527, 541 (1955) ("If, on the balancing of conveniences, it is fair to compel the defendant to come forward and he fails to do so, the judge may give judgment against him. But this judgment is not a declaration by the court that the facts necessary for liability have been established. No evidentiary or inferential process is involved, and rational connection is irrelevant. Rather, defendant has defaulted in his obligation and the court nuay inpose liability as a penalty for the default."). 
vant evidence peculiarly within his control. ${ }^{43}$

In title VII disparate impact cases, ${ }^{44}$ the courts have long and consistently held that plaintiffs can make out a prima facie case without showing a probability of the ultimate fact at issue. Thus plaintiffs' imtial case may consist solely of evidence that an einployer's policies have an adverse impact on minorities, despite the fact that the ultimate issue in a disparate impact case is whether there is an unjustiffed impact-an impact that is not job related. Once plaintiffs show impact, the burden is shifted to the employer to prove job-relatedness. ${ }^{45}$ The employer would suffer an adverse judgment on the inerits if it produced no rebuttal evidence, even though there is nothing necessarily unlawful about maintaming policies that have a disparate impact.

Courts have similarly shifted burdens of proof when doing so seemed appropriate in order to enforce the federal Constitution's ban on intentional discrimination, ${ }^{46}$ just as it has shifted burdens to enforce substantive law norms embodied in legislation governing civil rights ${ }^{47}$ and economic regulation, ${ }^{48}$ and in the cominon law of contract ${ }^{49}$ and

43. See F. JAMES \& G. HAZARD, supra note $25, \$ 7.9$, at 257 (access to evidence as basis for presumption of bailee's negligence when goods are damaged while in bailee's possession).

Access to evidence is one of the key considerations determining who bears the burden of proof in general. See 9 J. WIGMORE, EVIDENCE \$ 2486, at 290 (Chadbourne ed. 1981); E. CLEARY, MCCORMICK'S HANDBOOK OF THE LAW OF EvidENCE § 337, at 787 (2d ed. 1972); International Harvester Co. v. Ruckelslaus, 478 F.2d 615, 643 (D.C. Cir. 1973); United States v. New York, N.H. \& H.R.R., 355 U.S. 253, 256 n.5 (1957).

Burdine adopted a particular type of presumption known generally as the "bursting bubble" presumption, which shifts the burden of production, but not the burden of persuasion. When the party against whon the presumption operates produces the requisite information, the presuinption is said to disappear. Bursting bubble presumptions were established as the federal norm by rule 301 of the Federal Rules of Evidence. Such presunptions have been said to operate essentially as discovery devices. $1 \mathrm{~J}$. WeINSTEIN \& M. BERGER, supra note 42, at 301-11 (quoting unpublished memorandum from E. Cleary, Reporter, Advisory Committee on Rules of Evidence).

44. See supra notes 9-14 and accompanying text.

45. Griggs v. Duke Power Co., 401 U.S. at 432,433 n.9. In disparate impact cases the defendant has the burden of persuasion, as well as production, on the issue of job-relatedness. Id.

46. See, e.g., Castaneda v. Partida, 430 U.S. 482, 495 (1977) (showing of substantial underrepresentation of Mexican-Americans called to serve as grand jurors inakes out prima facie case of discriminatory purpose, shifting burden of proof to state); Alexander v. Louisiana, 405 U.S. 625, 631-32 (1972) (same, except blacks underrepresented); Keyes v. Scliool Dist. No. 1, 413 U.S. 189, 208-10 (1973) (finding of intentional segregation in one part of scliool system creates a presumption of intentional segregation in other parts of system, shifting burden of proof to defendant school board); $c f$. Swann v. Clarlotte-Mecklenburg Bd. of Educ., 402 U.S. 1, 18 (1971) (ability to classify school as "white school" or "Negro school" constitutes prima facie case of violation of equal protection clause).

47. See, e.g., Umited States v. Wilder, 222 F. Supp. 749, 753 (W.D. La. 1963) (under Civil Rights Act of 1960, statistical evidence created presumption of discrimination shifting burden of proof to defendants to show that blacks were not qualified for voter registration).

48. See, e.g., United States v. Aluminum Co. of America, 148 F.2d 416, 444-45 (2d Cir. 1945) (Hand, J.) (under the Slierman Act, once government showed that cartel intended to decrease inports, it was the cartel's burden to demonstrate that the inarket had been unaffected, in part because "they to whom the facts were nore accessible than to plaintiff ought to prove it"); 
tort..$^{50}$ Defendants' superior access to the relevant evidence is usually a major reason for shifting the burden in these cases. The courts ordinarily do not indicate exactly what level of probability plaintiffs inust show with respect to the particular fact at issue in order to justify shifting the burden of proof. But it is clear that there is no general principle requiring that plaintiffs show that the existence of the fact is inore likely than not, or indeed that plaintiffs show any other specific level of probability. Probability is simply one of a number of factors used by the courts in determining which party should bear the burden of proof on particular issues.

There is, therefore, ainple precedent for the principle represented by the D.C. Circuit's standard in Aikens. The real issue is whether the standard serves a useful purpose in furthering the substantive goals of title VII.

\section{B. Policy and Practicalities}

There has, of course, been extensive debate in various contexts about what Congress' goals were in enacting title VII. Battles are currently being waged over whether the disparate impact doctrine is consistent with those goals, and over whether the Act was designed to permit or to prohibit affirmative action for blacks. But there has never been any question as to the fact that one of the central goals of title VII is the elimination of intentional discrimination. The Aikens standard should be assessed in terins of whether it would further this goal by helping courts to determine fairly and accurately whether intentional discrimination has entered into an employer's decision-inaking process.

Fleming v. Harrison, 162 F.2d 789, 792 (8th Cir. 1947) (under the Emergency Price Control Act, once government made a prima facie case that defendant's prices exceeded statutory maxima, it was defendant's burden to show justification, because of the general rule placing burden of proof on party with special knowledge of the relevant facts).

49. See, e.g., Erving Paper Mills v. Hudson-Sharp Mach. Co., 332 F.2d 674, 677-78 (7th Cir.), cert. denied, 379 U.S. 946 (1964).

50. See, e.g., Jaffe, Res Ipsa Loquitur Vindicated, 1 Buffalo L. REv. 1, 6 (1951), discussing the doctrine of res ipsa loquitur in terms which are quite relevant to the issue in Aikens:

What justification can there be for putting to a jury a case in which a "rational" finding of liability cannot be made? The reason is two-fold. Our experience and understandimg of such situations indicates a substantial, if indetermimate, probability of negligence. In short, there is a substantial probability that the plaintiff may have a cause of action. Now ordinarily that fact alone would not warrant a judgment agaimst the defendant. But typically, if not invariably, in this class of case the defendant has greater access to the facts than the plaintiff. This is the significance of the usual requirement for res ipsa that the defendant be in "control" of the mischief-working instrumentality. Res ipsa loquitur rests on the notion that it is fair to treat the probability as the fact if the defendant has the power to rebut the inference.

See also 9 J. WIGMORE, supra note 43, \$2509, at 507 ("the particular force and justice of the rule [res ipsa loquitur], regarded as a presumption throwing upon the party charged the duty of producing evidence, consists in the circumstances that the clief evidence of the true cause, whether culpable or innocent, is practically accessible to him but inaccessible to the imjured person."). 


\section{Relationship Between the Prima Facie Case and the Presumption of Discrimination}

The strength of the relationship between the evidence on which a presumption is based, and the ultimate fact to be presumed, is one indicator of the fairness and utility of that presumption. If there is very hittle connection between the two, there would seem to be an increased risk that defendants will be dragged into court for no adequate reason, and even that the ultimate facts found will be erroneous. On the other hand, where a presumption is based on evidence which indicates that the fact to be presumed is reasonably likely, there would seem to be few risks in using a mandatory presumption to force defendants to produce evidence.

Under the Aikens standard, as formulated by the D.C. Circuit, there is a substantial relationship between the underlying evidence and the discrimination to be presumed. Thus to make out a prima facie case the D.C. Circuit held that plaintiff had to show that he satisfied all known qualifications, mcluding any discretionary qualifications that the employer revealed. Plaintiff was to be required on reinand to show that he was not passed over because of an "absolute or relative lack of qualifications."si The evidence revealed that white supervisors had made the promotional decisions at issue pursuant to a discretionary system, with the result that four whites were chosen over the black plaintiff for the positions at issue. It does not require a great logical leap to presume intentional discrimination under these circumstances. Title VII was passed as part of the Civil Rights Act of 1964, agamst a background of pervasive intentional discrimination. While much has changed over the last two decades, there can be little doubt that discriminatory attitudes are still common. And discretionary selection systems, relying on the subjective judgment of white decisionmakers, have long been deemed suspect by the courts because of their potential for masking and implementing bias-both conscious and unconscious. Indeed such systems have generally been held violative of title VII on these grounds, at least where they have resulted in adverse racial impact. ${ }^{52}$ Accordingly, whether or not plaintiff's prima facie proof in $A$ ikens demonstrated a probability of intentional discrimination, it certainly demonstrated a reasonable likelihood of such discrimination.

Moreover, rebuttable presumptions mandate that the presumed fact be accepted and judgment directed agamst the defendant, only after the defendant refuses to come forward with information. In the Aikens situation it is the employer who is in the best position to explain

51. 665 F.2d at 1060 .

52. The leading case is Rowe v. General Motors Corp., 457 F.2d 348 (5th Cir. 1972). 
how its promotional system operated, and why white candidates were preferred over the qualified black. As indicated below in Subsection 2, courts have generally felt that it is appropriate to place the burden of producing evidence on the party in control of that evidence. It is entirely reasonable to conclude that the employer is guilty of intentional discrimination if, in the face of a rule requiring that it come forward with an explanation of the nondiscriminatory reasons for its action, no such explanation is produced.

The Aikens presumption bears a striking similarity to Supreme Court doctrine developed in the jury discrimination cases, where the ultimate issue is whether state officials are guilty of intentional discrimmation, in violation of the federal Constitution. There the Court has held that a "presumption" of discrimination is created where plaintiffs produce evidence of: (1) a statistical disparity between the percentage of blacks in the relevant population and their percentage of jurors selected, together with (2) the existence of a subjective system for selecting jurors. ${ }^{53}$ The rationale for these decisions has included the notion that subjective systems lend themselves to abuse, together with the fact that defendant is in the best position to produce evidence as to the reasons for the exclusion of disproportionate numbers of blacks.

\section{Relationship of the Presumption to the Production of Relevant Information}

\section{a. Access to Information}

Presumptions are often created, in part, to further the discovery of vital information by putting the burden of production on the party with primary access to that information. ${ }^{54}$ The presuinption created by the D.C. Circuit in Aikens is well-designed to further the goal of gettimg before the court evidence that is essential to an understanding of how the employment decision at issue was made, and whether illicit intent played some part in it.

Thus under the Aikens standard, once plaintiffs have presented evidence that they satisfy all known qualifications, defendants are required to produce evidence as to how they actually evaluated qualifications. Placing the burden of production on the employer to explain how it assesses qualifications makes sense because the manner

53. See, e.g., Castaneda v. Partida, 430 U.S. 482, 494 (1977) (selection procedure that is "susceptible of abuse" supports presumption of discrimination raised by statistical showing); Turner v. Fouche, 396 U.S. 346, 360 (1970) (grand jury selection procedure that involves subjective judgment rather than objective criteria supports similar presumption raised by statistical showing).

54. See supra note 43 . 
in which a discretionary selection system operates is information uniquely within the employer's control. Such systems tend to operate in unknown and unforeseeable ways. Relatively few have been formalized and systematized. When discretion is built into an employment system, decisionmakers are ordinarily given broad leeway to assess a variety of subjective and objective factors they may deem relevant. Indeed the Government admits in its Aikens brief that often even the employer will not know how a particular discretionary decisionmaking process operates to determine who is most qualified until the actual selection decision is made. ${ }^{55}$ If plaintiffs cannot find out how a given discretionary system operates, they cannot make out a case that they are more qualified under that system than other candidates. ${ }^{56}$

\section{b. Discovery of Information}

Arguments have been made that presumptions are unneccessary for discovery purposes, given the development of the modern discovery system. The Government brief in Aikens rehes on such arguments, statimg that plamtiffs can find out everything in discovery that they could find out from the defendant's rebuttal at trial..$^{57}$

There is obvious appeal to the idea of forcing plaintiffs to find out everything possible relevant to their claim prior to trial, and then disinissing cases at the close of plaimtiff's initial proof where there is insufficient evidence to sustain a claim of intentional discrimination. Defendants would be protected froin the burden of putting on elaborate defenses to frivolous cases, and courts would be protected from having to sit through such defenses.

However, the value of presumptions in cases like Aikens carmot be so easily cast aside. The availability of discovery prior to trial is snnply not a complete and adequate substitute for the presumption at trial. The Government's argument flies in the face of the realities of litiga-

55. "An employer might realize that a particular quality or attribute would be desirable for the position he is filling only when he sees that quality in an applicant." Brief for Petitioner at 24 n.18, Aikens.

56. Justice Marshall argued when the Aikens case was previously before the Court that plaintiffs' difficulties in finding out how such systems operate justified imposing the burden of production on the employer:

An applicant who has satisfied the objective qualifications established by the employer for promotion may have no way of knowing what additional considerations the einployer rehed on in selecting a particular person among the pool of qualified applicants. This information is uniquely within the control of the employer, and thus it places an unfair burden on the plaintiff to require him, as part of his prima facie case, to guess what additional considerations the employer might have relied on and to prove that even under these considerations he was at least as qualified as the selected applicant.

United States Postal Serv. Bd. of Governors v. Aikens, 453 U.S. 902, 906 n.2 (1981) (Marshall, J., dissenting).

57. Brief for Petitioner at 31 , Aikens. 
tion. The simple truth is that in the absence of the Aikens presumption, it will often be impossible for plaintiffs to provide at the prima facie stage the kind of comparative evaluation of candidates demanded by the Government's standard. This is because first, the defendant's incentives to produce information im pre-trial discovery will likely be quite different from the incentives operating at trial, and second, the existence of the presumption at trial affects the dynamics of both the discovery process and the trial.

i. Incentives to Produce Information. Under the Government's proposed standard, the defendant would have little incentive to be forthcoming with information in pre-trial discovery. Burdine tells the employer that his ultimate burden is simply to articulate a non-discriminatory reason for his action. Defense counsel are likely to feel that this can be used to justify soine very conclusory statements im response to discovery requests regarding the nature of the employer's selection system, and the reasons white candidates were chosen over blacks. In theory, of course, the scope of discovery goes far beyond evidence that would be necessary or admissible at trial. However, defendants are not likely to be pumished for evasive answers; or for vague and general answers; or for refusals to respond that are coupled with colorable claims that the requests call for information that is umecessary, or that would be unduly burdensome to produce, or that is privileged. ${ }^{58}$ In order to force information from a reluctant defendant, plaintiffs will have to seek court orders to compel discovery, based on a showing as to why the particular information at issue is important.

Only plaintiffs with access to significant resources will be able to take full advantage of the discovery process. Depositions, motions to compel, and motions to impose sanctions are all expensive. Costs of such discovery, including costs for attorneys' fees, will ordmarily be recoverable only if plaintiffs ultimately prevail on the merits. ${ }^{59}$

Moreover, courts are unlikely to impose any sanction unless defendants are guilty of deliberately flouting obviously reasonable discovery requests, or of disobeying a direct and specific court order. And the kind of sanction that the government suggests as a possibility-a finding that plamtiff has met his prima facie case as discussed above at page 1209 -is extremely rare.

58. Defendants often successfully resist requests for discovery related to comparative qualifications on privacy and other grounds. See, e.g., Keyes v. Lenoir Rhyne College, 552 F.2d 579, 581 (4th Cir.), cert. denied, 434 U.S. 904 (1977) (upholding district court refusal to compel discovery of confidential evaluations of faculty members); McKillop v. Regents of the Univ. of Cal., $386 \mathrm{~F}$. Supp. 1270, 1277 (N.D. Cal. 1975) (district court refnsal to compel discovery based on state statutory "official information" privilege).

59. Title VII provides that the "prevailing party" may recover reasonable attorneys' fees. Civil Rights Act of 1964, $\$ 706(k), 42$ U.S.C. $\$ 2000 \mathrm{e}-5(\mathrm{k})$ (I976). 
The Government's standard would, moreover, provide defendants with a strong incentive to resist discovery, because if plaintiffs were unable to find out enough during discovery to make out a persuasive case of intentional discrimination during their intitial presentation of proof, they would lose without defendants ever having to present evidence.

The reality is, therefore, that plaintiffs would be denied the inforination essential to a prima facie case in many cases, and that in other cases they would obtam it only at the cost of wasteful discovery battles.

The Aikens presumption puts defendants in a very different position with respect to disclosing vital evidence. If they fail to come forward at trial with evidence that the judge considers adequate to satisfy their burden of production, they will suffer an adverse judginent on the merits. Moreover, while under Burdine defendants have no obligation to show that their articulated reasons are real or reasonable, and while technically the burden of persuasion will be on plaintiffs to prove illicit motive, defendants are likely to fear that if they introduce only the bare minimun of evidence required by Burdine, the factfinder is inore likely to be persuaded by plaintiff's showing of intent. Defendants are thus likely to introduce evidence in soine detail as to how their selection systems operate and how candidates' qualifications are evaluated, in order to show their good faith. It is this kind of detail that Burdine indicated may be necessary if plaintiffs are to prove such illicit intent as may exist.

Justice Powell, writing for a unanimous Court in Burdine, seems consciously to have considered these kinds of litigation practicalities. He specifically recognized that the pressures of the litigation situation-defendants' fear of losing-provide a useful incentive for defendants to produce meaningful, detailed information. ${ }^{60}$

60. In finding that plaintiff can expect a "clear and reasonably specific" explanation, affording it an adequate opportunity to demonstrate defendant's illicit intent, Justice Powell states:

[A]lthough the defendant does not bear a formal burden of persuasion, the defendant nevertheless retains an incentive to persuade the trier of fact that the employinent decision was lawful. Thus, the defendant normally will attempt to prove the factual basis for its explanation.

Burdine, 450 U.S. at 258 . The Government also recognizes these litigation practicalities. It notes that at trial the defendant will have an incentive to "introduce evidence that the plaintiff in fact had the slortcoming assigned as the reason for his rejection; that the successful candidate did not have that shortcoming or was otherwise better qualified; or that its practices generally slow no sign of discrimination." Brief for Petitioner at 32 (citing McDonnell Douglas Corp. v. Green, 411 U.S. at 804-05). The Government urges that employers slould not be subject to the burden of having to make such a slowing. But it would also be a burden for the employer to provide plaintiffs with comparable information at discovery. It seens clear that what the Government seeks is a standard that would free the employer from ever liaving to provide sucl information, whether at discovery or at trial, and free courts from ever liaving to assess complex analyses of comparative qualifications, whether upon plaintiffs initial case or upon defendant's rebuttal. 
The Aikens presumption thus operates as an alternative to discovery which may be necessary im a variety of situations due to limitations on plaintiffs' resources, the refusal of defendants to cooperate with discovery, and traditional judicial reluctance to enforce discovery obligations with effective sanctions.

ii. Dynamics of the Discovery and Trial Process. In addition, the Aikens presumption should affect the dynamics of the discovery process in such a way as to enable plaintiffs to learn what they need to witl relative efficiency. This is because the presumption means that defendants will have to be prepared to put on evidence at trial as to the reasons for their selection decisions, and the manner in which their selection procedures work. This in turn ineans that in discovery plaintiffs will be able to focus in on defendants' prospective proof, and nake pointed inquiries into what that proof will consist of, what witnesses defendants expect to rely on, and the like.

By contrast, under the Government's standard, even if plaintiffs were able to obtain in pre-trial discovery all needed information, discovery requests would have to be extraordinarily wide-ranging. Proof at trial would be similarly complicated. Given all the ways in which a particular discretionary system might measure various subjective and objective factors, plaintiff' connsel would have to explore in discovery and present at trial extensive evidence in an attempt to elimimate all possible rational explanations for why their clients might have been found less qualified than those selected. Plaintiffs' counsel would want access to all candidates' personnel files, and would want to examine im detail the various ways in which qualifications might have been ineasured by the employer. Under the Aikens standard, plaintiffs might seek inuch of the saine information, but they would not be required to, and they would not have to present an elaborate case of comparative qualifications based on a number of different hypothetical evaluative systems, $\dot{m}$ order to survive a defendant's motion for judgment at the close of plaintiff's case. Unlike plaintiff, defendant should know how its selection system operated in any particular case, and should be able to present that sinply and efficiently at the rebuttal stage.

The Aikens standard would do nothing to discourage plaintiffs from pursumg discovery. Plaintiffs' counsel liave a strong incentive to find out all they can in discovery, regardless of what the formal standard at the prima facie proof stage is. They will usually want to make the most persuasive case they can in their mitial presentation of proof,

Thus, the Government notes the difficulties of assessing comparative qualifications in cases where many kinds of criteria and many different subjective judgments may be considered relevant. It argues that "the only way to avoid such inquiries is a disinissal of the coinplaint . . . on the ground that plaintiff has failed to prove a prima facie case." Brief for Petitioner at 34 (emphasis added). 
to avoid any risk of dismissal; and they will be in a far better position to deal with defendant's rebuttal evidence if they know what to expect. The Aikens standard would simply operate to make discovery more efficient and effective, and to provide an alternative ineans of forcing the production of relevant evidence for those situations in which the discovery process has failed. And it should operate to expedite presentation of proof at trial.

Fimally, the Aikens standard serves some functions that discovery cannot serve. It forces the employer to the stand to make an accounting of some sort to the factfinder. This may be far more revealing than would be the disjointed story told by hostile employer witnesses called by plaintiff as a result of what he learned in formal discovery. ${ }^{61}$

Elimination of the Aikens presumption is not necessary to free defendants and the courts from the burden of frivolous suits. Burdine's substantive standard makes it extremely difficult for plaintiffs ultimately to win any case in which the employer relies on a discretionary selection system involving elements of subjective judgment. Such a system, by its very nature, has a great deal of pliability. Einployers can with relative ease come up with non-discriminatory explanations for their selection decisions. These explanations will not likely look so outrageous as to enable plaimtiffs to persuade the factfinder that the explanations are inere pretexts, shielding intentional discrimination. Since plaintiffs will prevail only in cases where they are able to prove that defendants' explanations are not credible, or to find the proverbial sinoking gun, they would be foolish to pursue cases in which they have no good reason to believe that such evidence will be available. Unless plaintiffs ultimately prevail on the merits, they cannot recover the costs of brimging suit. ${ }^{62}$ If the claims are found to be frivolous, costs-including attorneys' fees-may be assessed against plaimtiffs. ${ }^{63}$ There are thus strong financial dismcentives against brimging non-meritorious claims to court.

\section{CONCLUSION}

The Government argues in its Aikens brief that its proposed standard should be adopted because otherwise the disparate treatment doctrime would impose excessive burdens on employers to defend their

61. See Jaffe, supra note 50, at 13-14 (arguing that discovery procedures have not made the res ipsa loquitur doctrine obsolete, because "being able to ask an opponent questions, albeit without risk, is inferior to the right to compel him to make on his own initiative a full accounting").

62. See supra note 59 .

63. Christiansburg Garment Co. v. EEOC, 434 U.S. 412, 421 (1978) ("A district court may in its discretion award attorney's fees to a prevailing defendant in a Title VII case upon a finding that the plaintiff's action was frivolous, unreasonable, or without foundation even though not brought in subjective bad faith."). 
practices in court. ${ }^{64}$ However, the Supreme Court just recently provided significant protections for employers when it held in Burdine that they had no burden of persuasion in a disparate treatınent case but, imstead, had simply to produce a nondiscriminatory explanation for such treatinent. Moreover, as indicated above, the disparate treatment doctrine as defined by Aikens poses a relatively limited burden on or threat to employers in the context of discretionary, subjective decisionmaking on the managerial level.

The disparate treatment doctrine does, nonetheless, remain important. It inay be the only available route to challenging complex einployment systeins that rely on discretion and subjective judgment, smce it is not clear that courts will apply the disparate inpact doctrine to such systems. And if there is a general cutback on the impact doctrine's applicability, the disparate treatment doctrine may come imcreasingly to define the ineaning of title VII.

Moreover, the disparate treatment challenge is often an essential step in discovering how the employer's system operates. Thus, in rebuttal to the disparate treatment challenge, the employer may reveal for the first time what kinds of objective criteria and subjective judgments it relies on in making employment decisions. This discovery provides plaintiffs with at least the possibility of asking the court to consider further, inore specific challenges to particular practices or criteria under either the impact or the treatment doctrine. ${ }^{65}$

A crucial aspect of the courts' interpretation of title VII to date has been the insistence that employers and their representatives come into court to defend themselves. It has been through this process that the courts have learned what various employment systems look like. This understanding has enabled the courts to develop and refine title VII jurisprudence to deal with the problems perceived ${ }^{66}$ Burdine recognized the importance of this tradition in holding that einployers would at least be required to produce relevant inforination at trial. The danger of the Government's position in Aikens is that, by encouraging dismissal at the close of plaintiffs' initial presentation of evidence, it would deprive courts of inforination vital to their understanding of challenged employment systems, and to the continumg development of appropriate title VII law.

64. Brief for Petitioner at 11.

65. Bartholet, supra note 8, at 1006.

66. Id. at $990-98$. 